\title{
Dendrometric characteristics and basic wood density of eucalyptus clones in different spacing
}

\author{
Ana Paula Cardoso Tavares ${ }^{1}$, Thelma Shirlen Soares ${ }^{1}$, Edmilson Santos Cruz $^{1}$ \\ ${ }^{1}$ Universidade Federal de Jataí, Campus Jatobá, Jataí, Goiás, Brasil. E-mail: ana_paula.tavares@yahoo.com, thelmasoares@ufg.br, \\ edmilson_santos_cruz@ufg.br
}

Received: 06/02/2020; Accepted: 11/08/2020.

\begin{abstract}
This study aimed to analyze the effect of two planting spacing on dendrometric characteristics and basic wood density of eucalyptus clones. The experiment in the municipality of Jataí-GO, Brazil, used a randomized complete block design with three replications, in which the spacing $(3.0 \mathrm{~m} \times 2.0 \mathrm{~m}$ and $3.0 \mathrm{~m} \times 3.0 \mathrm{~m})$ were allocated to the plots and the clones $(3335,3336$ and 3487) in the subplots. Diameter at breast height (dbh), total height (HT), total volume (VT), basic density $(\mathrm{db})$, stem biomass $\left(\mathrm{B}_{\mathrm{S}}\right)$, leaf and branch biomass $\left(\mathrm{B}_{\mathrm{LB}}\right)$ and total biomass $\left(\mathrm{B}_{\mathrm{T}}\right)$ were evaluated. The data were submitted to analysis of variance, followed by the Tukey test for comparison of means at the 5\% probability level. It was found that the dbh and VT characteristics were not influenced by the planting spacing nor by the clone types. The HT was influenced by the spacing with the highest value $(26.3 \mathrm{~m})$ verified in the spacing $3 \mathrm{~m} \times 3 \mathrm{~m}$. The $\mathrm{db}$ was influenced only by the clone types and the clones 3335 and 3487 presented the highest values ( 0.46 and $0.41 \mathrm{~g} . \mathrm{cm}^{-3}$, respectively). The $\mathrm{B}_{\mathrm{S}}, \mathrm{B}_{\mathrm{LB}}$ and $\mathrm{B}_{\mathrm{T}}$ were influenced only by clones with higher yields with clones 3335 and 3487 . There were no significant interactions for any of the evaluated characteristics.
\end{abstract}

Keywords: Eucalyptus spp., dendrometry, yield, space arrangements.

\section{Características dendrométricas e densidade básica da madeira de clones de eucalipto em diferentes espaçamentos}

\section{RESUMO}

Este estudo teve por objetivo analisar o efeito de dois espaçamentos de plantio em características dendrométricas e densidade básica da madeira de clones de eucalipto. O experimento no município de Jataí-GO utilizou o delineamento em blocos casualizados em esquema de parcelas subdivididas, com três repetições, no qual os espaçamentos ( $3,0 \mathrm{~m}$ x 2,0 m e 3,0 m x 3,0 m) foram alocados nas parcelas e os clones (3335, 3336 e 3487) nas subparcelas. Foram avaliadas as características diâmetro a 1,30 m de altura do solo (dap), altura total (HT), volume total $(\mathrm{VT})$, densidade básica $(\mathrm{db})$ e biomassa do fuste $\left(\mathrm{B}_{\mathrm{F}}\right)$, biomassa de folhas e galhos $\left(\mathrm{B}_{\mathrm{FG}}\right)$ e biomassa total $\left(\mathrm{B}_{\mathrm{T}}\right)$. Os dados obtidos foram submetidos à análise de variância, seguida do teste de Tukey para comparação de médias, ao nível de 5\% de probabilidade. Verificou-se que as características dap e VT não foram influenciadas pelos espaçamentos de plantio, nem pelos tipos de clones. A HT foi influenciada pelo espaçamento, sendo o maior valor $(26,3 \mathrm{~m})$ verificado no espaçamento $3 \mathrm{~m} \times 3 \mathrm{~m}$. A db foi influenciada apenas pelos tipos de clone, sendo que os clones 3335 e 3487 apresentaram os maiores valores $\left(0,46\right.$ e $0,41 \mathrm{~g} \cdot \mathrm{cm}^{-3}$, respectivamente). $\mathrm{B}_{\mathrm{F}}, \mathrm{B}_{\mathrm{FG}}$ e $\mathrm{B}_{\mathrm{T}}$ foram influenciadas apenas pelos clones com maiores produções com os clones 3335 e 3487 . Não ocorreram interações significativas para nenhuma característica avaliada.

Palavras-chave: Eucalyptus spp., dendrometria, produção, espaçamentos. 
One of the main silvicultural decisions in the planning of forest production is the choice of planting spacing, since this is the first practice that can cause changes in the characteristics of the future tree (Akhtar et al., 2008; Nolan et al., 2015; Rocha et al., 2016; Rocha et al., 2018), especially in the case of fast growth as the Eucalyptus plantations (Stape et al., 2010).

The choice of planting spacing for a given species or clone in silvicultural is highly relevant because it conditions the amount of natural resources available to the growth of each tree. This influences plant growth and survival rates and wood productivity per hectare, affecting management and harvesting practices and, consequently, forest production costs (Stape and Binkley, 2010; Lima et al., 2013; Forrester et al., 2013).

Inadequate spacing can accentuate the effects of water deficiency on plants, decreasing forest productivity, due to the intense intraspecific competition for water, light, nutrients, and space (Leles et al., 1998).

Highly productive and intensely managed forests incorporating the most advanced methods in silviculture is one solution to the problem of growing demand for wood and other forest products (Häggman et al., 2013).

The behavior of a planted forest in the different types of management can provide changes in the quality of the wood, influencing the desired final product and, consequently, its commercial value (Eloy et al., 2016). The search for superior quality material that meets the demanding timber market is growing every year. Such behavior is reflected in the different forest segments from silvicultural and forest improvement, finishing in the forest-based technology sector. Thus, the knowledge of the variability between the available materials and the relationships between the technological and dendrometric characteristics are extremely importance (Gonçalves et al., 2010).

The dendrometric variables (height, diameter, basal area, individual volume and volume/ha) undergo changes with the advancement of settlement age and are subject to some growth trends as a function of spacing (Leite et al., 2006). There is a diversity of responses in the development of these variables, both negative and positive among the species, due to the increase in plant spacing.

Since spacing is one of the conditioning factors of forest production that can be easily controlled by the manager and considering that it can cause reflections on the growth rates of the forest and on the properties of the wood, it is important to evaluate the effect of this silvicultural practice on the dendrometric characteristics and to ensure forest production, quality and proper use of the product obtained.

In this context, this study aimed at evaluating the behavior of dendrometric variables and the basic density of three eucalyptus clones in two planting spacing.
The study was conducted at the Federal University of Goiás, Jataí Regional, in the municipality of Jataí, in the southwest of Goiás state, located at coordinates $17^{\circ} 56$ 'S and $51^{\circ} 43^{\prime} \mathrm{W}$. According to Köppen classification, the climate of the site is Aw, with annual precipitation values of $1644.9 \mathrm{~mm}$ and temperature of $23.7^{\circ} \mathrm{C}$ (INMET, 2013). The soil is a dystroferric Dark Red Latosol.

The experimental design was a randomized complete block design in split plots. The effect of two planting spacing ( $3 \times 2 \mathrm{~m}$ and $3 \times 3 \mathrm{~m}$ ) was tested in the plots. The treatments of the subplots corresponded to three clonal materials of the hybrid E. grandis $x$ E. urophylla named as clone 127 (clones 3335, 3336, 3487). In each subplot, 40 trees were planted.

After 60 months of planting the trees, the diameter at breast height (dbh), total height (HT) of all trees of each subplot was measured. Then, four medium trees were selected in each subplot (based on the values closest to the mean dbh and HT) to be slaughtered for the rigorous counting and determination of the total biomass. The cubing was performed by the Smalian method, measured at heights $0.1 ; 1.3 ; 2.0 ; 4.0 ; 6.0 \mathrm{~m}$, and so on up to $4 \mathrm{~cm}$ in diameter of the stem with the bark.

To obtain the density in each sample tree, $2.5 \mathrm{~cm}$ thick discs were removed at $0,25,50,75$ and $100 \%$ of the commercial height. From these disks, samples were taken for the determination of the basic density in the laboratory by the method of immersion. The discs removed were sectioned in four wedges, passing through the medulla. Two opposing wedges were used to determine the basic density of wood according to the Brazilian standard NBR 11941 (ABNT, 2003). The mean basic density of the tree was considered as the arithmetic mean of the longitudinal sampling points in the trunk of the trees, without considering the dbh position according to the methodology used by Protásio et al. (2014). The estimate of the stem biomass was then obtained by multiplying the volume by the respective basic density.

The trees samples were stripped and their components (leaves, branches and stem) were weighed in the field. After determining the total fresh biomass of leaves and branches, samples of these components were taken, which were conditioned in sealed plastic bags and taken to the laboratory to determine the fresh biomass of the sample. Afterward, mass for the determination of the dry biomass, they were transferred to paper bags and dried in a forced ventilation oven at $65^{\circ} \mathrm{C}$ until reaching constant.

According to Hsing et al. (2016), the total dry biomass of leaves and branches were determined from the values of total fresh biomass and fresh and dry biomass of the respective component (leaves or branches), according to general expression: total dry biomass $=$ (total fresh biomass component $\mathrm{x}$ dry component sample biomass) $\div$ fresh component sample biomass. The total dry biomass of the tree was obtained from the biomass sum of the 
stem, leaves, and branches. The obtained data analyzed the variance and $\mathrm{F}$ test with the means compared by the Tukey test at $5 \%$ of probability.

The analyses of variance indicated non-significant interaction between clones and spacing $(\mathrm{P} \leq 0.05)$. The results of the analysis of variance and the means test are presented in Tables 1 and 2, respectively.

Significance was only observed in the influence of spacing on total height (HT) and clones on density (d), stem biomass $\left(\mathrm{B}_{\mathrm{s}}\right)$, leaf and branch biomass $\left(\mathrm{B}_{\mathrm{LB}}\right)$ and total biomass $\left(\mathrm{B}_{\mathrm{T}}\right)$ and not significant interactions occurred for no assessed characteristics.

The mean value observed for the dbh was $15.6 \mathrm{~cm}$, not influenced by the spacing nor by the clones. The influence of the distance between plants and consequently in the variable diameter is verified in several studies on spacing (Berger et al., 2002; Akhtar et al., 2008; Ferreira et al., 2014; Moulin et al., 2017). These studies prove that the greater the distance between plants, the less competition for growth factors, the greater the diameter of the tree. However, the results did not present statistical differences for the dbh variable in this study because only two spatial arrangements were used.

The total height (HT) data presented a significant difference between the spacing, where the spacing $3 \mathrm{~m} \mathrm{x}$ $3 \mathrm{~m}$ presented the highest mean values of height with $26.3 \mathrm{~m}$.

Ribeiro et al. (2017) evaluated 16 planting spacing for an interspecific hybrid clone of Eucalyptus grandis and Eucalyptus urophylla and verified an increase in the average height of the trees as the spacing was enlarged.

Schneider (1993) reports about the difficulty in expressing and justifying the effect of higher densities over the height growth, however, he affirms that the height growth is higher in relation with the diameter on densities that contemplate larger number of individuals per area unit, that is, in conditions of competition for light and nutrients, the trees have a favored longitudinal growth. In general, the results of commercial surveys and plantations have shown that the diameter is a highly responsive characteristic of spacing, while the effects on height had controversial results. There are cases in which the average height of the plants increases when the spacing is bigger, and in other cases, the result is the opposite (Botelho, 1998), as those influences are dependent of each species' characteristics and can be either positive or negative with the raise or shortening of spacing (Benin et al., 2014).

The individual total volume of the trees (VT) did not have a significant difference between the treatments evaluated with an average value of $0.2633 \mathrm{~m}^{3}$. The obtained results differ from the reports observed in different studies in which the larger individual volume occurs in the wide spacing. In the larger spacing, the best individual yield in volume is obtained, meaning that in larger arrangements, the plant has a better growth in relation to the smaller plant spacing due to the greater availability of medium resources. This tendency is justified by the greater competition between trees in the smaller spacing due to a greater occupation of the area (Martins et al., 2009; Silveira et al., 2014).

The difference in volumetric production from one spacing to another is only dependent on the time required to obtain the full occupancy of the site, with a tendency of a similar maximal yield per unit area for all stocking density (Soares et al., 2018).

Only clones effects for wood density (d) was observed with clones 3335 and 3487 having the highest average values of $0.46 \mathrm{~g} / \mathrm{cm}^{3}$ and $0.41 \mathrm{~g} / \mathrm{cm}^{3}$, respectively. Wood density can vary between species, trees and even within the same tree (Henry et al. 2010; Sotelo Montes et al., 2012). The natural variation of wood density between species is caused by the amount of woody matter per unit volume or the amount of voids in it (Monteoliva et al., 2015) results in a wide range of wood densities within the genus (Barotto et al., 2017).

Regarding the spacing, the results obtained corroborate with those obtained by Sereghetti et al. (2015) and Benin et al. (2017), who stated that the basic density is not affected by the spacing.

Table 1 - Summary of the analysis of variance for diameter at breast height (dbh), total height (HT), total volume (VT), basic wood density $(\mathrm{db})$, stem biomass $\left(\mathrm{B}_{\mathrm{S}}\right)$, leaf and branches biomass $\left(\mathrm{B}_{\mathrm{LB}}\right)$ and total biomass $\left(\mathrm{B}_{\mathrm{T}}\right)$ for three eucalyptus clones implanted at two different spacing in Jataí-GO.

\begin{tabular}{|c|c|c|c|c|c|c|c|c|}
\hline \multirow{2}{*}{ Sources of Variation } & \multirow{2}{*}{ Degrees of Freedom } & \multicolumn{7}{|c|}{ Average Squares } \\
\hline & & $d b h$ & HT & VT & db & $\mathbf{B}_{\mathbf{S}}$ & $\mathbf{B}_{\text {LB }}$ & $\mathbf{B}_{\mathbf{T}}$ \\
\hline Blocks & 2 & 0.20 & 2.14 & 3.04 & 38.65 & 3.01 & 3.48 & 18.02 \\
\hline Spacing & 1 & $15.31^{\mathrm{ns}}$ & $10.50^{*}$ & $174.04^{\mathrm{ns}}$ & $0.30^{\mathrm{ns}}$ & $29.47^{\mathrm{ns}}$ & $34.09^{\mathrm{ns}}$ & $176.46^{\mathrm{ns}}$ \\
\hline Error a & 2 & 3.09 & 0.17 & 42.25 & 23.71 & 12.47 & 14.43 & 74.67 \\
\hline Clones & 2 & $1.96^{\mathrm{ns}}$ & $1.38^{\mathrm{ns}}$ & $6.73^{\mathrm{ns}}$ & $126.95^{*}$ & $3.50^{*}$ & $4.05^{*}$ & $20.96^{*}$ \\
\hline Clones x Spacing & 2 & $5.95^{\mathrm{ns}}$ & $1.03^{\mathrm{ns}}$ & $67.49^{\text {ns }}$ & $1.23^{\mathrm{ns}}$ & $9.28^{\mathrm{ns}}$ & $10.74^{\mathrm{ns}}$ & $55.57^{\mathrm{ns}}$ \\
\hline Error b & 8 & 5.20 & 2.44 & 66.45 & 19.42 & 8.75 & 10.12 & 52.39 \\
\hline \multicolumn{2}{|c|}{ Coefficient of Variation (\%) } & 10,7 & 1,7 & 24,6 & 11,5 & 32,7 & 31,5 & 30,8 \\
\hline \multicolumn{2}{|c|}{ Coefficient of Variation (\%) } & 13,9 & 6,1 & 30,9 & 10,8 & 27,4 & 26,7 & 28,9 \\
\hline
\end{tabular}

* significant with $\mathrm{P} \leq 0.05 \mathrm{~ns}=$ not significant with $\mathrm{P} \leq 0.05$. 
Table 2 - Mean values for diameter at breast height (dbh), total height (HT), total volume (VT), basic wood density (d), stem biomass (Bs), leaf and branch biomass ( $\mathrm{BLB}_{\mathrm{LB}}$ and total biomass ( $\mathrm{B}_{\mathrm{T}}$ ) for three eucalyptus clones implanted at two different spacing in Jataí-GO*.

\begin{tabular}{cccccccc}
\hline Factor & $\boldsymbol{d} \boldsymbol{b h}(\mathbf{c m})$ & $\mathbf{H T}(\mathbf{m})$ & $\mathbf{V T}\left(\mathbf{m}^{\mathbf{3}} / \mathbf{t r e e}\right)$ & $\mathbf{d b}\left(\mathbf{g} / \mathbf{c m}^{\mathbf{3}}\right)$ & $\mathbf{B s}\left(\mathbf{K g} / \mathbf{m}^{\mathbf{3}}\right)$ & $\mathbf{B}_{\mathbf{L B}}\left(\mathbf{K g} / \mathbf{m}^{\mathbf{3}}\right)$ & $\mathbf{B}_{\mathbf{T}}\left(\mathbf{K g} / \mathbf{m}^{\mathbf{3}}\right)$ \\
\hline $3 \mathrm{~m} \times 2 \mathrm{~m}$ & $15.4 \mathrm{a}$ & $24.7 \mathrm{~b}$ & $0.2322 \mathrm{a}$ & $0.41 \mathrm{a}$ & $95.1 \mathrm{a}$ & $12.4 \mathrm{a}$ & $107.5 \mathrm{a}$ \\
$3 \mathrm{~m} \times 3 \mathrm{~m}$ & $17.3 \mathrm{a}$ & $26.3 \mathrm{a}$ & $0.2944 \mathrm{a}$ & $0.41 \mathrm{a}$ & $120.6 \mathrm{a}$ & $13.3 \mathrm{a}$ & $133.9 \mathrm{a}$ \\
\hline 3335 & $15.7 \mathrm{a}$ & $26.0 \mathrm{a}$ & $0.2515 \mathrm{a}$ & $0.46 \mathrm{a}$ & $115.2 \mathrm{a}$ & $17.7 \mathrm{a}$ & $132.5 \mathrm{a}$ \\
3336 & $16.6 \mathrm{a}$ & $25.1 \mathrm{a}$ & $0.2721 \mathrm{a}$ & $0.37 \mathrm{~b}$ & $99.9 \mathrm{~b}$ & $14.5 \mathrm{~b}$ & $114.4 \mathrm{~b}$ \\
3487 & $16.8 \mathrm{a}$ & $25.4 \mathrm{a}$ & $0.2661 \mathrm{a}$ & $0.41 \mathrm{a} \mathrm{b}$ & $108.5 \mathrm{a}$ & $17.6 \mathrm{a}$ & $126.1 \mathrm{a}$ \\
\hline
\end{tabular}

* Means with same letter in each column do not differ statistically (Tukey, $\mathrm{P} \leq 0.05$ ).

The stem, branches and leaves and total biomass were influenced only by the evaluated clones. The results obtained in this study for stem biomass coincide with those found by Berger et al. (2002) who, evaluating the quality of the wood of a clone of $E$. saligna under the effect of spacing and fertilization, the biomass was not influenced by space vital. Ribeiro et al. (2017) observed that the biomass production per unit area decreased with the increase in plant spacing.

According to Müller et al. (2005), over time, the amount of biomass stored in a given forest site tends to equalize at different planting spacing. Therefore, it is necessary to know the dynamics of biomass production from the initial stages of growth to define planting densities and to select the most suitable genetic material for timber production.

The stem, leaves and branches and total biomass was superior for clones 3335 and 3487. Alves et al. (2007) evaluating the biomass production in leaf leaves and stem of 7 hybrids Eucalyptus in Pernambuco verified differences between treatments. Bernardo et al. (1998) observed that the stem and total aboveground biomass per tree increased with spacing. Authors also the response of total stand stem biomass to planting density differed among the clones.

The spacings only influenced the total height with greater height for spacing $3 \mathrm{~m}$ x $3 \mathrm{~m}$. Clones 3335 and 3487 presented higher values for basic wood density, stem biomass, leaf and branch biomass and total biomass. There were no significant interactions for any of the evaluated characteristics.

\section{Bibliographic References}

ABNT. Associação Brasileira de Normas Técnicas, 2003. NBR 11941: madeira - determinação da densidade. Rio de Janeiro, ABNT, 6 p.

Akhtar, J., Saqib, Z.A., Qureshi, R.H., Haq, M.A., Iqbal, M.S., Marcar, N.E., 2008. The effect of spacing on the growth of Eucalyptus camaldulensis on salt-affected soils of the Punjab, Pakistan. Canadian Journal of Forest Research, 38(9), 24342444.

Alves, A.M.C., Silva, J.A.A., Ferreira, R.L.C., Barreto, L.P., 2007. Quantificação da produção de biomassa em clones de eucaliptos com 4,5 anos, no Polo Gesseiro do Araripe-PE. Revista de Ciências Agrárias, 48(1), 161-173.
Barotto, A.J., Monteoliva, S., Gyenge, J., Martinez Meier, A., Moreno, K., Tesón, N., Fernández, M.E., 2017. Wood density and anatomy of three Eucalyptus species: implications on hydraulic conductivity. Forest Systems, 26(1), e010.

Benin, C.C., Watzlawick, L.F, Hillig, E., 2017. Propriedades físicas e mecânicas da madeira de Eucalyptus benthamii sob efeito do espaçamento de plantio. Ciência Florestal, 27(4), 1375-1384.

Benin, C.C., Wionzek, F.B., Watzlawick, L.F., 2014. Initial assessments on the plantation of Eucalyptus benthamii Maiden et Cambage deployed in different spacing. Brazilian Journal of Applied Technology for Agricultural Science, 7(1), 55-61.

Berger, R., Schneider, P.R., Finger, C.A.G., Haselein, C.R., 2002. Efeito do espaçamento e da adubação no crescimento de um clone de Eucalyptus saligna Smith. Ciência Florestal, 12(2), 75-87.

Bernardo, A.L., Reis, M.G.F., Reis, G.G., Harrison, R.B., Firme, D.J., 1998. Effect of spacing on growth and biomass distribution in Eucalyptus camaldulensis, E. pellita and E. urophylla plantations in southeastern Brazil. Forest Ecology and Management, 104(1-3), 1-13.

Botelho, S.A., 1998. Espaçamento, in: Scolforo, J.R.S. Manejo Florestal. Lavras, UFLA/FAEPE, p. 381-406.

Eloy, E., Silva, D.A., Schmidt, D., Trevisan, R., Caron, B.O., Elli, E.F., 2016. Effect of planting age and spacing on energy properties of Eucalyptus grandis W. Hill Ex Maiden. Revista Árvore, 40(4), 749-758.

Ferreira, D.H.A.A., Leles, P.S.S., Machado, E.C., Abreu, A.H.M., Abílio, F.M., 2014. Crescimento de clone de Eucalyptus urophylla $\mathrm{x}$ E. grandis em diferentes espaçamentos. Floresta, 44(3), 431-440.

Forrester, D.I., Wiedemann, J.C., Forrester, R.I., Bake, T.G., 2013. Effects of planting density and site quality on mean tree size and total stand growth of Eucalyptus globulus plantations. Canadian Journal of Forest Research, 43(9), 846-851.

Gonçalves, F.G., Oliveira, J.T.S., Silva, G.F., Nappo, M.E., Tomazelo Filho, M., 2010. Parâmetros dendrométricos e correlações com propriedades tecnológicas em um híbrido clonal de Eucalyptus urophylla $\mathrm{x}$ Eucalyptus grandis. Revista Árvore, 34(5), 947-959.

Häggman, H., Raybould, A., Borem, A., Fox, T., Handley, L., Hertzberg, M., Lu, M.Z, Macdonald, P., Oguchi, T., Pasquali, G., Pearson, L., Peter, G., Quemada, H., Séguin, A., Tattersall, K., Ulian, E., Walter, C., McLean, M., 2013. Genetically engineered trees for plantation forests: key considerations for environmental risk assessment. Plant Biotechnology Journal, 11(7), 785-798. 
Henry, M., Besnard, A., Asante, W.A., Eshun, J., Adu-Bredu, S., Valentini, R., Bernoux, M., Saint-André, L., 2010. Wood density, phytomass variations within and among trees, and allometric equations in a tropical rainforest of Africa. Forest Ecology and Management, 260(8), 1375-1388.

Hsing, T.Y., Paula, N.F., Paula, R.C., 2016. Características dendrométricas, químicas e densidade básica da madeira de híbridos de Eucalyptus grandis x Eucalyptus urophylla. Ciência Florestal, 26(1), 273-283.

INMET - Instituto Nacional de Meteorologia, 2013. BDMEP Banco de Dados Meteorológicos para Ensino e Pesquisa: Série Histórica - Dados Diários de 01/01/1982 a 31/12/2012 Estação: 83464 - Jataí-GO. https://bit.ly/3iz8ElT (acessado 11 dezembro 2013).

Leite, H.G., Nogueira, G.S., Moreira, A.M., 2006. Efeito do espaçamento e da idade sobre variáveis de povoamentos de Pinus taeda L. Revista Árvore, 30(4), 603-613.

Leles, P.S.S., Reis, G.G., Reis, M.G.F, Morais, E.J., 1998. Relações hídricas e crescimento de árvores de Eucalyptus camaldulensis e Eucalyptus pellita sob diferentes espaçamentos na região de cerrado. Revista Árvore, 22(1), 41-50.

Lima, R., Inoue, M.T., Figueiredo Filho, A., Araújo, A.J., Machado, S.A., 2013. Efeito do espaçamento no desenvolvimento volumétrico de Pinus taeda L. Floresta e Ambiente, 20(2), 223-230.

Martins, R.J., Seixas, F., Stape, J.L., 2009. Avaliação técnica econômica de um harvester trabalhando em diferentes condições de espaçamento e arranjo de plantio em povoamento de eucalipto. Scientia Forestalis, 41(97), 253-263.

Monteoliva, S., Barotto, A.J., Fernández, M.E., 2015. Anatomía y densidad de la madera en Eucalyptus: variación interespecífica e implicancia en la resistencia al estrés abiótico. Revista Facultad Agronomía, 114(2), 209-217.

Moulin, J.C., Arantes, M.D.C., Oliveira, J.G.L., Campinhos, E., Gomes, F., Vidaurre, G.B., 2017. Efeito do espaçamento, idade e irrigação no volume e densidade básica do eucalipto. Floresta e Ambiente, 24: e00073914.

Müller, M.D., Couto, L., Leite, H.G., Brito, J.O., 2005. Avaliação de um clone de eucalipto estabelecido em diferentes densidades de plantio para produção de biomassa e energia. Biomassa e Energia, 2(3), 177-186.

Nolan, L., Aust, W.M., Barrett, S.M., Bolding, M.C., Brown, K., McGuire, K., 2015. Estimating costs and effectiveness of upgrades in forestry best management practices for stream crossings. Water, 7(12), 6946-6966.

Protásio, T.P., Neves, T.A., Reis, A.A., Trugilho, P.F., 2014. Efeito da idade e clone na qualidade da madeira de Eucalyptus spp visando à produção de bioenergia. Ciência Florestal, 24(2), 465-477.

Ribeiro, M.D.S.B., Blanco Jorge, L.A., Mischan, M.M., Santos, A.L., Ballarin, A.W., 2017. Avaliação da produção de biomassa do fuste de um clone híbrido de eucalipto sob diferentes espaçamentos. Ciência Florestal, 27(1), 31-45.

Rocha, M.F.V., Pereira, B.L.C., Oliveira, A.C., Pego, M.F.F., Veiga, T.R.L.A., Carneiro, A.C.O., 2018. Influence of plant spacing on the bark properties of a Eucalyptus clone. Revista Árvore, 42(5), e420501.

Rocha, M.F.V., Vital, B.R., Carneiro, A.C.O., Carvalho, A.M.M.L., Cardoso, M.T., Hein, P.R.G., 2016. Effects of plant spacing on the physical, chemical and energy properties of Eucalyptus wood and bark. Journal of Tropical Forest Science, 28(3), 243-248.

Schneider, P.R., 1993. Introdução ao manejo florestal. Santa Maria, UFSM/CEPEF/FATEC.

Sereghetti, G.C., Lanças, K.P., Sartori, M.S., Rezende, M.A., Soler, R.R., 2015. Efeito do espaçamento no crescimento e na densidade básica da madeira de Eucalyptus urophylla $\mathrm{x}$ Eucalyptus grandis em florestas de ciclo curto. Energia na Agricultura, 30(3), 257-262.

Silveira, E.R., Reiner, D.A., Smaniotto, J.R., 2014. Efeito do espaçamento de plantio na produção de madeira e serapilheira de Eucalyptus dunni na região Sudoeste do Paraná. Revista Técnico-Científica, 2, 1-9.

Soares, T.S., Gouveia Junior, W.V., Matias, R.A.M., Cruz, E.S., 2018. Effect of stocking density on energetic productivity of an eucalyptus stands managed under a short rotation system. Nativa, 6(2), 165-169.

Sotelo Montes, C., Weber, J.C., Silva, D.A., Andrade, C., Muñiz, G.I.B., Garcia, R.A., Kalinganire, A., 2012. Effects of region, soil, land use and terrain type on fuelwood properties of five tree/shrub species in the Sahelian and Sudanian ecozones of Mali. Annals of Forest Science, 69(6), 747-756.

Stape, J.L., Binkley, D., 2010. Insights from full-rotation Nelder spacing trials with Eucalyptus in São Paulo, Brazil. Southern Forests, 72(2), 90-97.

Stape, J.L., Binkley, D., Ryan, M.G., Fonseca, S., Loos, R.A., Takahashi, E.N., Silva, C.R., Silva, S.R., Hakamada, R.E., Ferreira, J.M.A., Lima, A.M.N., Gava, J.L., Leite, F.P., Andrade, H.B., Alves, J.M., Silva, G.G.C., Azevedo, M.R., 2010. The Brazil eucalyptus potential productivity project: Influence of water, nutrients and stand uniformity on wood production. Forest Ecology and Management, 259(9), 16841694. 